\title{
Determination of Camylofin Dihydrochloride and Nimesulide in Pharmaceutical Preparation by Gas Chromatography
}

\author{
Rajeev Kumar R. Singh ${ }^{1,2}$, Manapragada V. Rathnam ${ }^{1}$, Sangeeta J. Singh ${ }^{2}$, Raju V. K. Vegesna ${ }^{2}$ \\ ${ }^{1}$ Department of Chemistry, B. N. Bandodkar College of Science, Thane, India \\ ${ }^{2}$ Versapharm Incorporated, Warminister, USA \\ E-mail: kumarrajeevs@gmail.com
}

Received February 27, 2011; revised May 22, 2011; accepted June 1, 2011

\begin{abstract}
This research paper describes simple analytical method for determination of Camylofin dihydrochloride and Nimesulide in tablet formulation by Gas chromatography method. Benzoic acid was used as internal standard. Validation was carried out in compliance with the International Conference on Harmonization guidelines. The method utilized GC (Agilent Technologies 6890 N Network GC system with FID detector), and RTX-5 capillary column (5\% diphenyl-95\% dimethyl polysiloxane), $30 \mathrm{~m} \times 0.53 \mathrm{~mm}, 1.5 \mu \mathrm{m}$ as stationary phase. Helium was used as the carrier gas at a flow rate of $1.5 \mathrm{~mL} \cdot \mathrm{min}^{-1}$. The proposed method was validated for linearity, LOD, LOQ, accuracy, precision, ruggedness and solution stability. It can be conveniently adopted for routine quality control analysis.
\end{abstract}

Keywords: Capillary Column, Gas Chromatography, Pharmaceutical Preparations, Camylofin Dihydrochloride, Nimesulide

\section{Introduction}

Camylofin dihydrochloride is 3-methylbutyl 2-(2-diethylaminoethylamino)-2-phenyl-acetate hydrochloride is a drug used an antispasmodic [1]. Nimesulide N-(4-Nitro2-phenoxyphenyl) methanesulfonamide.Nimesulide is a relatively COX-2 selective, non-steroidal anti-inflammatory drug (NSAID) with analgesic and antipyretic properties. Its approved indications are the treatment of acute pain, the symptomatic treatment of osteoarthritis and primary dysmenorrhoea in adolescents and adults above 12 years old [2].The structure of the drug is shown in Figure 1. One such combination contains $50 \mathrm{mg}$ of Camylofin dihydrochloride and $100 \mathrm{mg}$ of Nimesulide.

The literature survey revealed that there is no method for the simultaneous determination of these compounds. There are other publications for determination of these compounds but in combination with other components by other analytical techniques like HPLC, spectrophotometry and colorimetric [4-16].There is a GC method reported for the analysis of Camylofin dihydrochloride [17]. There are, however, no publications for simultaneous determination of these drugs in such pharmaceutical preparation. Therefore a GC method was developed for

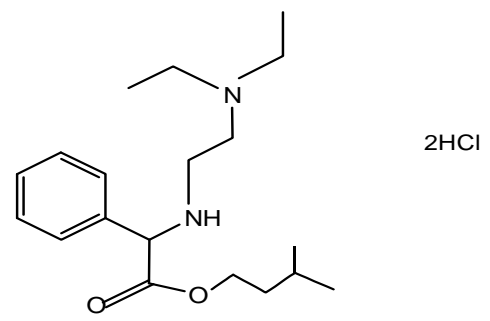

Camylofin dihydrochloride $\left(\mathrm{C}_{19} \mathrm{H}_{32} \mathrm{~N}_{2} \mathrm{O}_{2}, 2 \mathrm{HCl}\right)$

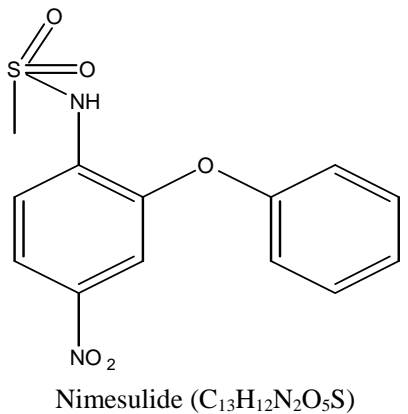

Figure 1. Structure of camylofin dihydrochloride and nimesulide. 
determination of camylofin dihydrochloride and Nimesulide from their dosage form. The method described is simple, fast, precise and accurate for simultaneous determination of Camylofin dihydrochloride and Nimesulide from pharmaceutical preparation. The method is very cost and time effective since it does not require any mobile phase preparation and can be easily adapted to Quality control testing laboratory.

\section{Materials and Methods}

\subsection{Chemicals and Reagents}

Anafortan $\mathrm{N}$ tablets manufactured by Khandelwal lab, India were procured from the market. Anafortan N tablets is a combination of Camylofin dihydrochloride 50 mg and Nimesulide $100 \mathrm{mg}$. Methanol was from Qualigens. All dilutions were performed in standard volumetric flasks.

\subsection{Apparatus}

The analysis was performed by using the analytical balance Mettler Toledo, the GC used is of Agilent Technologies $6890 \mathrm{~N}$ Network GC system with FID detector. Column used in GC is a capillary column RTX-5, $30 \mathrm{~m} \times$ $0.53 \mathrm{~mm}, 1.5 \mu \mathrm{m}$. Photo stability studies were carried out in a photo stability chamber (Sanyo, Leicestershire, UK). Thermal stability studies were carried out in a dry air oven (Lindberg-Blue, USA).

\subsection{Experimental}

Method development and optimization of chromatographic conditions:

To develop a suitable GC method for the analysis of camylofin dihydrochloride and Nimesulide in their dosage form, different capillary columns were tried [18]. The criteria employed for selecting the columns for the analyses of the drugs were cost involve, time required for the analysis, better separation of the components. Chromatographic separation was preformed with Agilent
Technologies 6890 N Network Gas chromatography system, equipped with auto sampler and a flame ionization detector. Chromatograms and data were recorded by means of Empower software. RTX-5 capillary column (Crossbond 50\% diphenyl-95\% dimethyl polysiloxane) was used for analysis. The column dimension was $30 \mathrm{~m}$ $\times 0.53 \mathrm{~mm}, 1.5 \mu \mathrm{m}$. The system was run at a flow rate of $1.5 \mathrm{~mL} \cdot \mathrm{min}^{-1}, 1 \mu \mathrm{L}$ of sample was injected in the chromatographic system and flame ionization detector was used for simultaneous determination of Camylofin dihydrochloride and Nimesulide. Helium was used as a carrier gas. Oven temperature was kept $180^{\circ} \mathrm{C}$ and increased at a rate of $10^{\circ} \mathrm{C} \cdot \mathrm{min}^{-1}$ to $280^{\circ} \mathrm{C}$ and held at $280^{\circ} \mathrm{C}$ for 15.0 minutes. Injector temperature and detector temperature were kept at $250^{\circ} \mathrm{C}$ and $280^{\circ} \mathrm{C}$ respectively. The split ratio was kept at 50:1. A summary of method development and optimization is described in Table 1.

\subsubsection{Preparation of Standard Stock Solutions}

The stock solution of Camylofin dihydrochloride (1250 $\mu \mathrm{g} \cdot \mathrm{mL}^{-1}$ ) was prepared by dissolving $126.1 \mathrm{mg}$ of Camylofin dihydrochloride (99.9\%) in methanol in a standard $100 \mathrm{~mL}$ volumetric flask (stock solution A). The stock solution of Nimesulide $\left(2500 \mu \mathrm{g} \cdot \mathrm{mL}^{-1}\right)$ was prepared by dissolving $250.8 \mathrm{mg}$ of Nimesulide (99.8\%) in methanol in a standard $100 \mathrm{~mL}$ volumetric flask (stock solution B). Internal standard (benzoic acid) stock solution $\left(5000 \mu \mathrm{g} \cdot \mathrm{mL}^{-1}\right)$ was prepared by dissolving 500.9 mg of benzoic acid (99.6\%) in methanol in a $100 \mathrm{~mL}$ standard volumetric flask (stock solution C).

Transferred $10.0 \mathrm{~mL}$ of each stock solution A, B \& C to a $50 \mathrm{~mL}$ volumetric flask and diluted up to the mark with methanol. This is working standard solution.

\subsubsection{Sample Preparation}

For analysis of the tablet dosage form, twenty tablets were weighed individually and their average weight was determined. The tablets were crushed to fine homogenous powder and quantity equivalent to ten tablets were transferred in a $200 \mathrm{~mL}$ volumetric flask. Added about 100 $\mathrm{mL}$ of Methanol to the volumetric flask, shaken for 10 minutes and then sonicated for 15 minutes. The solu tion

Table 1. Summary of optimization of chromatographic conditions.

\begin{tabular}{llll}
\hline Column used & Carrier gas & Flow rate & Observation \\
\hline $\begin{array}{l}\text { DBWax, } 30 \mathrm{~m} \times 0.53 \mathrm{~mm}, 1.0 \mu \mathrm{m} \\
\text { capillary column }\end{array}$ & Helium & $1.2 \mathrm{~mL} \cdot \mathrm{min}^{-1}$ & No peaks observed \\
$\begin{array}{l}\text { DB624, } 30 \mathrm{~m} \times 0.32 \mathrm{~mm}, 1.8 \mu \mathrm{m} \\
\text { capillary column }\end{array}$ & Helium & $1.2 \mathrm{~mL} \cdot \mathrm{min}^{-1}$ & Peak shape for both components not good \\
$\begin{array}{l}\text { RTX1, } 30 \mathrm{~m} \times 0.53 \mathrm{~mm}, 1.0 \mu \mathrm{m} \\
\text { capillary column }\end{array}$ & Helium & $1.5 \mathrm{~mL} \cdot \mathrm{min}^{-1}$ & Poor resolution and low response \\
$\begin{array}{l}\text { RTX5, } 30 \mathrm{~m} \times 0.53 \mathrm{~mm}, 1.5 \mu \mathrm{m} \\
\text { capillary column }\end{array}$ & Helium & $1.5 \mathrm{~mL} \cdot \mathrm{min}^{-1}$ & Good resolution and good peak shape \\
\hline
\end{tabular}


was allowed to stand at room temperature for 20 - 30 minutes and filtered through Whatman no. 41 filter paper. The residue was washed with Methanol and the combined filtrate was made up to the mark with the same solvent.

$5.0 \mathrm{~mL}$ of filtrate was quantitatively transferred to a 50 $\mathrm{mL}$ volumetric flask, $10.0 \mathrm{~mL}$ of internal standard solution was added to it, and solution was diluted up to the mark with methanol. The identities of both the compounds were established by comparing retention time of the sample solution with those of standard solution.

\subsection{Validation Parameters}

The method validation was carried out as per ICH guidelines [19]. Various method validation parameters were performed.

\subsubsection{System Suitability Test}

System suitability tests are used to verify that the reproducibility of the equipment is adequate for the analysis to be carried out. System suitability tests were performed as per the USP 31 to confirm the suitability and reproducibility of the system. Various parameters such as tailing factor and resolution between the peaks were obtained.

\subsubsection{Specificity}

Specificity of the method was evaluated by injecting diluents, placebo, individual Camylofin dihydrochloride and Nimesulide and sample solution in to the GC system to check any interference to the peaks.

\subsubsection{Linearity}

Linearity was evaluated by analysis of working standard solutions of Camylofin dihydrochloride and Nimesulide of seven different concentrations. The range of linearity was from $250-750 \mu \mathrm{g} \cdot \mathrm{mL}^{-1}$ for Nimesulide and 125 $375 \mu \mathrm{g} \cdot \mathrm{mL}^{-1}$ for Camylofin dihydrochloride. The peak area ratio and concentration of each drug was subjected to regression analysis to calculate the calibration equations and correlation coefficients.

\subsubsection{LOD and LOQ/Sensitivity}

Sensitivity was determined by establishing the limit of detection (LOD) and limit of quantification (LOQ). The limit of detection (LOD) and limit of quantitation (LOQ) were established at signal-to-noise ratio of 3:1 and 10:1 respectively.

\subsubsection{Accuracy}

Accuracy was determined over the range $50 \%$ to $150 \%$ of the sample concentration. Calculated amount of Camylofin dihydrochloride and Nimesulide from standard stock solution was added in placebo to attain 50\%, 100\% and $150 \%$ of sample concentration. Each sample was prepared in triplicate at each level. Blank and standard preparations were injected and chromatograms were recorded.

\subsubsection{Precision}

Repeatability was studied by carrying out system precision. System precision was determined from results for six replicate injections of the mixed standard solutions. Method precision was determined from results from five independent determinations at $100 \%$ of the test concentrations of Camylofin dihydrochloride and Nimesulide in the product.

\subsubsection{Ruggedness (Intermediate Precision)}

Ruggedness study was demonstrated by injecting six individual sample preparations at $100 \%$ of the test concentrations of Camylofin dihydrochloride and Nimesulide on different day using another column and system.

\subsubsection{Robustness}

By deliberate change in experimental condition the resolution between Methylparaben, Camylofin dihydrochloride and Nimesulide were evaluated. To study the effect of flow rate on system suitability parameters, 0.2 units changed i.e. 1.3 and $1.7 \mathrm{~mL} \cdot \mathrm{min}^{-1}$. The effect of column temperature was studied at $170^{\circ} \mathrm{C}$ and $190^{\circ} \mathrm{C}$. The injector temperature and detector temperature were kept constant.

\subsubsection{Stability of Solution}

The solution stability of Camylofin dihydrochloride and Nimesulide was carried out by leaving the test solutions of sample in a tightly capped volumetric flask at room temperature for 72 hours. The same sample solutions were assayed for 24 hours interval up to the study period against freshly prepared standard solution.

\subsubsection{Stress Testing (Forced Degradation Study)}

To further confirm the stability indicating nature of the method, the drug was subjected to stress conditions as per the ICH recommended test conditions [20,21].

To study the effect of acid, $5 \mathrm{~mL}$ of $2 \mathrm{M} \mathrm{HCl}$ was added to the sample and the mixture was kept for 48 hours at room temperature. To study the effect of base, 5 $\mathrm{mL}$ of $1 \mathrm{~N} \mathrm{NaOH}$ solution was added to the sample and the mixture kept for 3 hours at room temperature. To study the effect of oxidizing conditions, $5 \mathrm{~mL}$ of $3 \% \mathrm{v} / \mathrm{v}$ $\mathrm{H}_{2} \mathrm{O}_{2}$ was added to the sample and the mixture was kept for 48 hours at room temperature.

To study the effect of temperature sample was kept in an oven at $80^{\circ} \mathrm{C}$ for 5 days. 
To study the effect of light sample was and kept in a photostability chamber for 5 days.

\section{Results and Discussion}

\subsection{System Suitability}

System suitability tests are used to verify that the reproducibility of the equipment is adequate for the analysis to be carried out. System suitability tests were performed as per the USP 31 to confirm the suitability and reproducibility of the system. The \% RSD values were found to be satisfactory and meeting the requirements of USP 31 (RSD less than 2.0\%). A typical GC chromatogram for simultaneous determination of camylofin dihydrochloride and Nimesulide from pharmaceutical formulation is shown in Figure 2 and Figure 5. System suitability parameters are mentioned in Table 2.

\subsection{Specificity}

No peak was observed at the retention time of Camylofin dihydrochloride, Nimesulide and Benzoic acid in diluents and Placebo chromatogram. Hence the method was specific.

\subsection{Linearity}

Linearity was evaluated by analysis of working standard solutions of Camylofin dihydrochloride and Nimesulide of seven different concentrations. The range of linearity was from $125 \mu \mathrm{g} \cdot \mathrm{mL}^{-1}$ to $375 \mu \mathrm{g} \cdot \mathrm{mL}^{-1}\left(250 \mu \mathrm{g} \cdot \mathrm{mL}^{-1}\right.$ is $100 \%$ level) for Camylofin dihydrochloride and 250 $\mu \mathrm{g} \cdot \mathrm{mL}^{-1}$ to $750 \mu \mathrm{g} \cdot \mathrm{mL}^{-1}$ (500 $\mu \mathrm{g} \cdot \mathrm{mL}^{-1}$ is $100 \%$ level) for Nimesulide. The peak area ratio and concentration of each drug was subjected to regression analysis to calculate the calibration equations and correlation coefficients. Figure 6 represents the linearity plots of Camylofin dihydrochloride and Nimesulide. The regression data obtained for the Camylofin dihydrochloride and Nimesulide is represented in Table 3. The result shows that within the concentration range mentioned above, there was an excellent correlation between peak area ratio and concentration.

\subsection{LOD and LOQ/Sensitivity}

The LOD and LOQ of Camylofin dihydrochloride and Nimesulide was experimentally determined by six injections of each drug. The LOD of Camylofin dihydrochloride and Nimesulide was found to be $1.2 \mu \mathrm{g} \cdot \mathrm{mL}^{-1} \& 1.6$ $\mu g \cdot \mathrm{mL}^{-1}$ respectively. The LOQ of Camylofin dihydrochloride and Nimesulide was found to be $2.1 \mu \mathrm{g} \cdot \mathrm{mL}^{-1}$ \& $2.7 \mu \mathrm{g} \cdot \mathrm{mL}^{-1}$ respectively.

\subsection{Accuracy}

Accuracy was expressed as the percentage of analytes recovered by the assay. Table 4 lists the recoveries of the drug from a series of spiked concentrations. The results indicate the method is highly accurate for simultaneous determination of Camylofin dihydrochloride and Nimesulide.

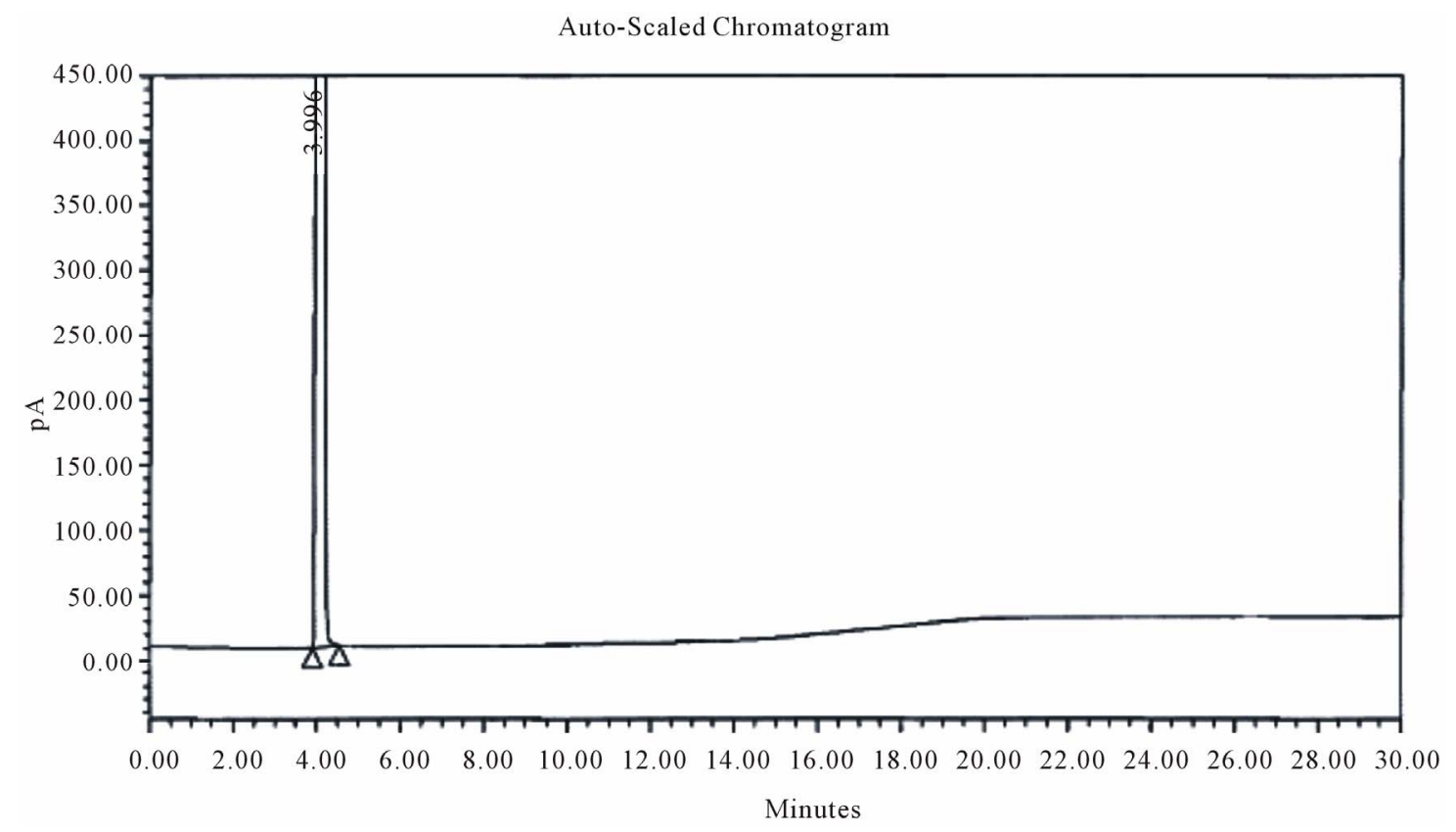

Figure 2. Chromatogram of diluent. 


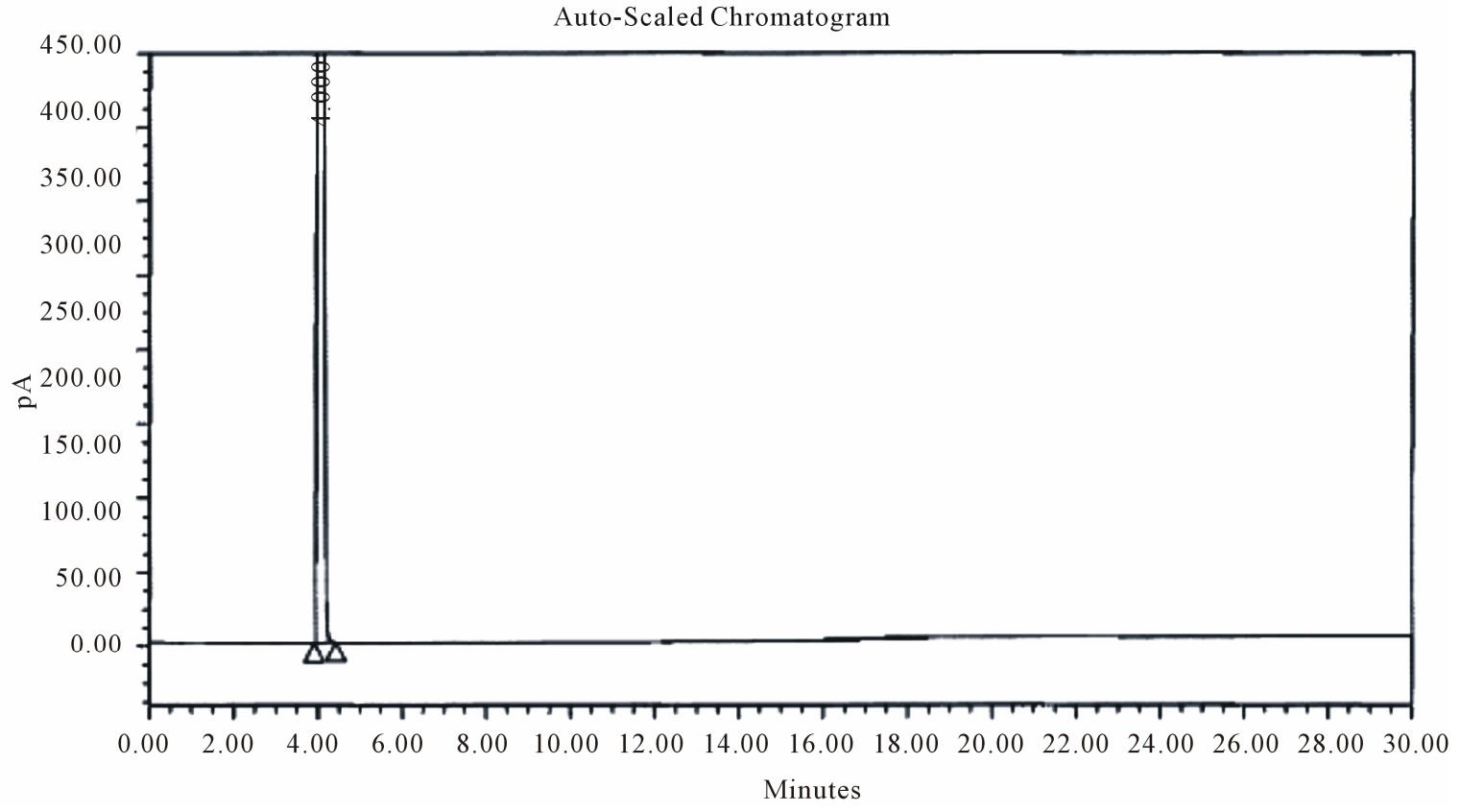

Figure 3. Chromatogram of placebo.

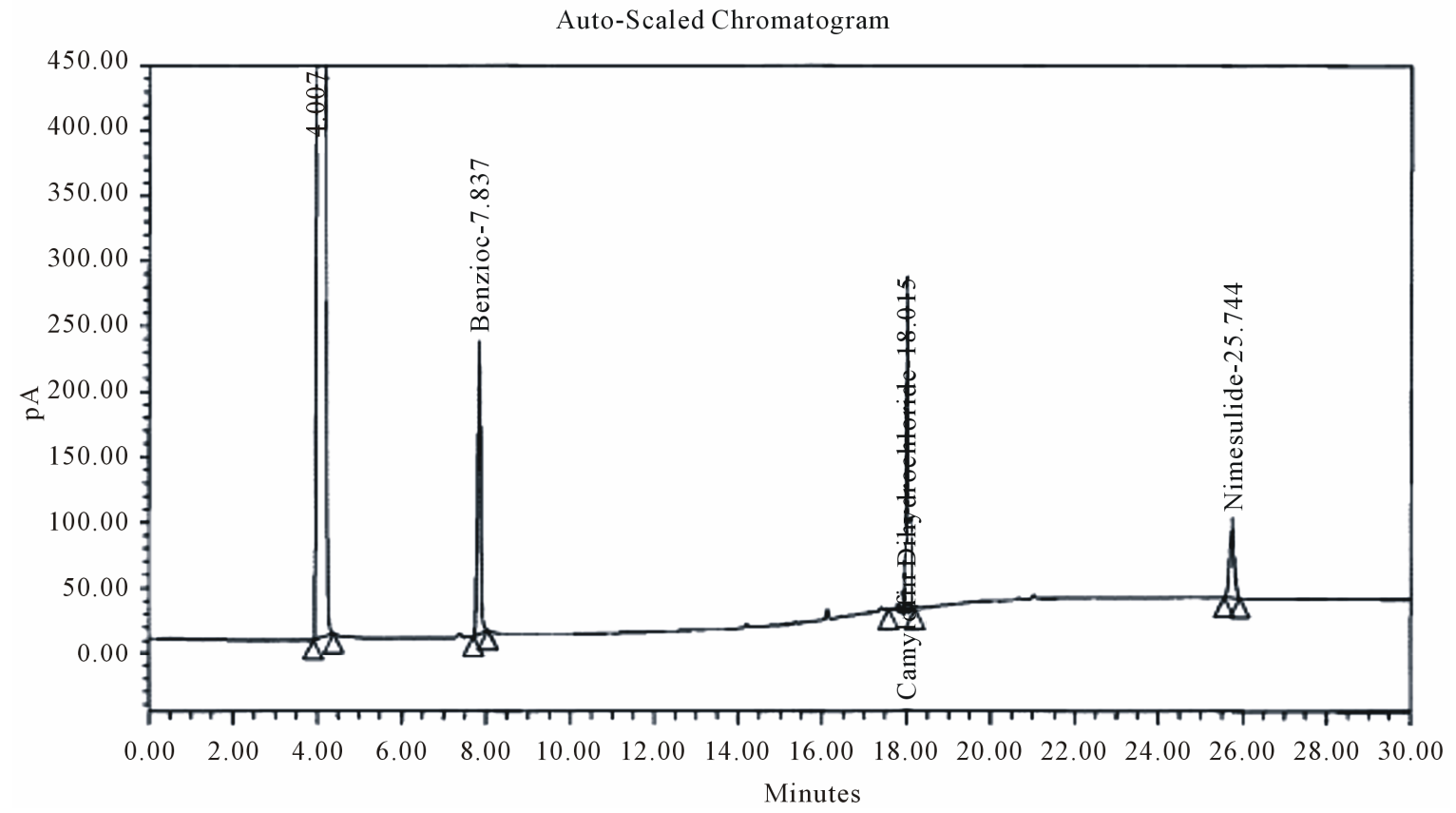

Figure 4. Chromatogram of Camylofin dihydrochloride and Nimesulide with benzoic acid (internal standard) in standard preparation. Nimesulide-25.744.

\subsection{Precision}

The values of the relative standard deviation of five replicate injections of the standard solution containing both the analytes of interest were within the limits of not more than 2.0\%. Refer Table 5.

\subsection{Ruggedness (Intermediate Precision) and Robustness}

Ruggedness study was done by injecting six individual sample preparations at $100 \%$ of the test concentrations of Camylofin dihydrochloride and Nimesulide on different 


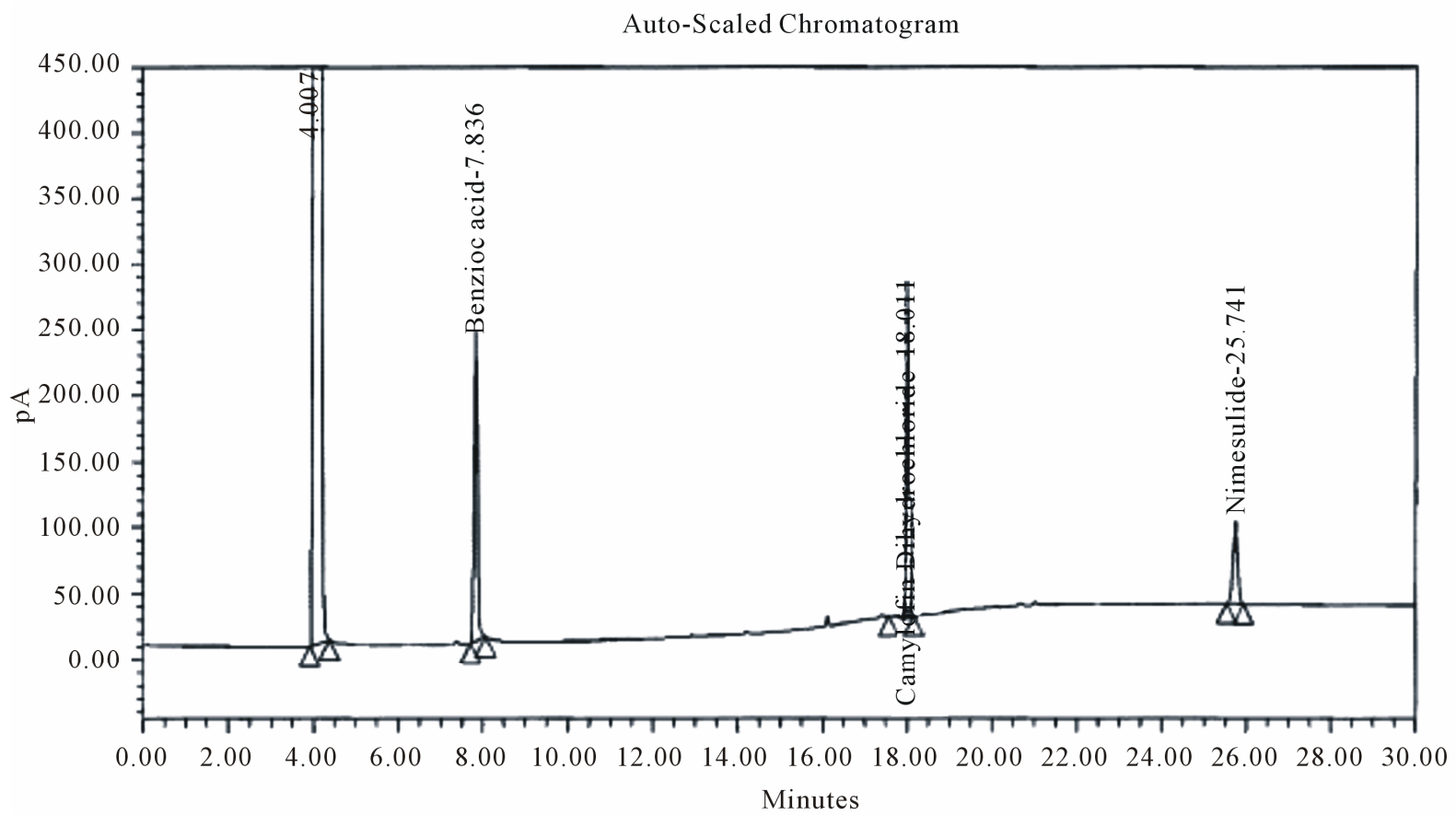

Figure 5. Chromatogram of Camylofin dihydrochloride and Nimesulide with Benzoic acid (internal standard) in sample preparation.

Table 2. Results of system suitability.

\begin{tabular}{cccc}
\hline Parameters & $\begin{array}{c}\text { Benzoic } \\
\text { acid }\end{array}$ & $\begin{array}{c}\text { Camylofin } \\
\text { dihydrochloride }\end{array}$ & Nimesulide \\
\hline Resolution & NA & 78.2 & 42.8 \\
Tailing factor & 1.0 & 1.2 & 1.0 \\
Theoretical plates & 62551 & 375888 & 211127 \\
\% RSD & NA & 0.45 & 0.51 \\
\hline
\end{tabular}

day and different GC system. The mean \% Assay obtained was compared with mean \% Assay of precision study. The relative standard deviation (RSD) was less than 2\%. Refer Table 6.

The method was not affected by deliberate variations such as flow rate and column temperature.

\subsection{Solution Stability}

The \% assay of Camylofin dihydrochloride and Nimesulide were checked in the test solutions. The \% RSD of assay of Camylofin dihydrochloride and Nimesulide during solution stability experiment was within 1.0. No significant changes were observed in the content of Camylofin dihydrochloride and Nimesulide during solution stability experiment. Sample solutions used during the experiment were stable upto the study period of 72 hours.
The results are reported in Table 7 .
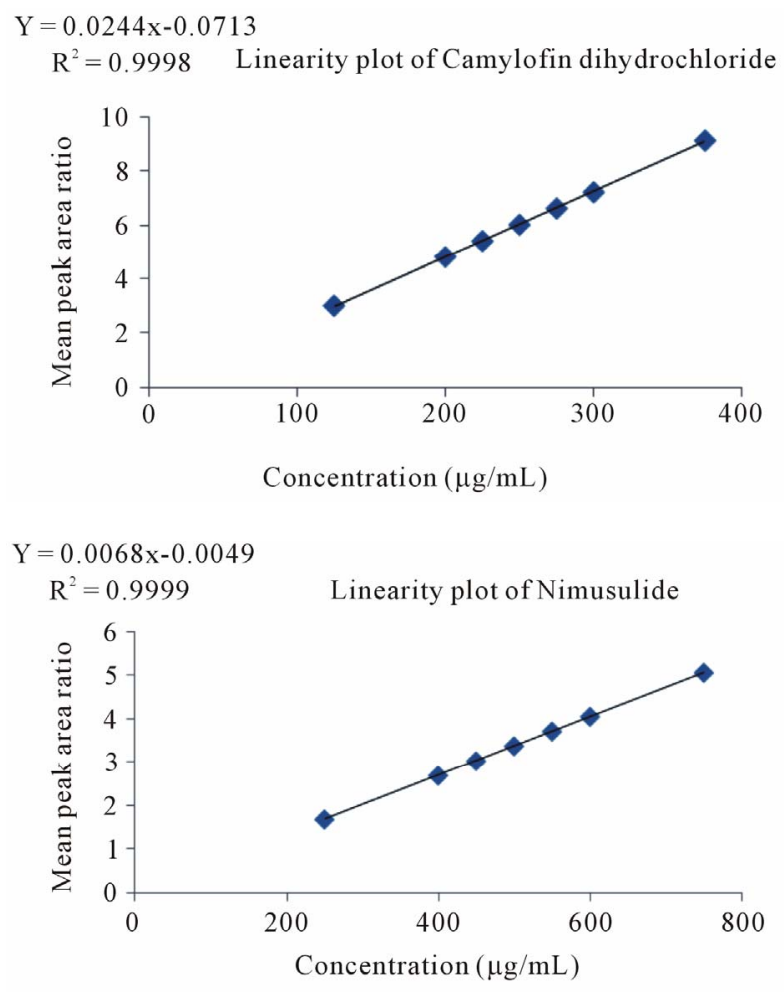

Figure 6. Linearity plot of camylofin dihydrochloride and nimesulide. 
Table 3. Results of linearity study.

\begin{tabular}{cccc}
\hline Analyte & Slope & Intercept & Correlation coefficient $\left(\mathbf{r}^{2}\right)(\mathbf{n}=7)$ \\
\hline Camylofin dihydrochloride & 0.0244 & -0.0713 & 0.9998 \\
Nimesulide & 0.0068 & -0.0049 & 0.9999 \\
\hline
\end{tabular}

Table 4. Accuracy of method.

\begin{tabular}{|c|c|c|c|c|c|}
\hline Analyte & $\begin{array}{c}\text { Recovery } \\
\text { Level (\%) }\end{array}$ & $\begin{array}{c}\text { Amount added } \\
\left(\mu \mathrm{g} \cdot \mathrm{mL}^{-1}\right)\end{array}$ & $\begin{array}{c}\text { Amount recovered } \\
\qquad\left(\mu \mathrm{g} \cdot \mathrm{mL}^{-1}\right)\end{array}$ & $\begin{array}{c}\text { RSD (\%) } \\
\quad \mathrm{N}=3\end{array}$ & (\%) Recovery \\
\hline \multirow{2}{*}{ Camylofin dihydrochloride } & 50 & 125.12 & 124.88 & 0.32 & 99.81 \\
\hline & 150 & 375.36 & 375.94 & 0.21 & 100.15 \\
\hline Nimesulide & 50 & 250.74 & 249.15 & 0.25 & 99.37 \\
\hline
\end{tabular}

Table 5. Results of precision experiment.

\begin{tabular}{ccc}
\hline Results & Camylofin dihydrochloride & Nimesulide \\
\hline Drug found in mg/tab (mean) & 49.81 & 100.22 \\
\% Mean Assay & 99.62 & 100.22 \\
\% RSD & 0.47 & 0.29 \\
\hline
\end{tabular}

Table 6. Ruggedness of assay experiment.

\begin{tabular}{lcc}
\hline Results & Camylofin dihydrochloride & Nimesulide \\
\hline Drug found in mg/tab (mean) & 50.23 & 100.64 \\
\% Mean Assay & 100.46 & 100.64 \\
\% RSD & 0.55 & 0.42 \\
\% Difference wr.t. Precision & 0.84 & 0.42 \\
\hline
\end{tabular}

Table 7. Results of solution stability.

\begin{tabular}{ccccc}
\hline Condition & $\begin{array}{c}\text { \% Assay of Camylofin } \\
\text { dihydrochloride }\end{array}$ & $\begin{array}{c}\text { \% Difference w.r.t. } \\
\text { initial assay }\end{array}$ & \% Assay of Nimesulide & $\begin{array}{c}\text { \% Difference w.r.t. } \\
\text { initial assay }\end{array}$ \\
\hline Initial & 99.6 & NA & 100.2 & NA \\
24 hours & 99.4 & 0.2 & 100.0 & 0.2 \\
48 hours & 99.0 & 0.6 & 99.5 & 0.7 \\
72 hours & 98.4 & 1.2 & 99.1 & 1.1 \\
\hline
\end{tabular}

\subsection{Stress Testing (Forced Degradation Study)}

The \% degradation of Camylofin dihydrochloride in acid hydrolysis, base hydrolysis, oxidation, thermal and photolytic was $10.43,18.20,4.87,1.53$ and 2.20 respectively with respect to the control sample. The \% degradation of Nimesulide in acid hydrolysis, base hydrolysis, oxidation, thermal and photolytic was 4.34, 21.99, 3.97, 1.97 and 7.34 respectively with respect to the control sample. The mass balance was found to be more than $97.0 \%$. The peaks of the degradation products were well resolved from the principle peaks. The results of stress studies are tabulated in Tables 8(a)-(b).

\section{Conclusions}

The method after being completely validated showed satisfactory data for all the method validation parameters. 
Table 8. (a): Summary of forced degradation results for Camylofin dihydrochloride; (b): summary of forced degradation results for Nimesulide.

(a)

\begin{tabular}{ccccc}
\hline Stress condition & Time & \% Assay of Camylofin 2HCl & $\begin{array}{c}\text { \% Degradation } \\
\text { w.r.t control }\end{array}$ & $\begin{array}{c}\text { Mass balance } \\
\text { (\% assay+ \% degradation products) }\end{array}$ \\
\hline Control & $\mathrm{NA}$ & 99.74 & $\mathrm{NA}$ & 100.14 \\
Acid hydrolysis $(2 \mathrm{M} \mathrm{HCl})$ & $48 \mathrm{~h}$ & 89.31 & 10.43 & 98.01 \\
Base hydrolysis $(1 \mathrm{~N} \mathrm{NaOH})$ & $3 \mathrm{~h}$ & 81.54 & 18.20 & 97.52 \\
Oxidation $\left(3 \% \mathrm{H}_{2} \mathrm{O}_{2}\right)$ & $48 \mathrm{~h}$ & 94.87 & 4.87 & 99.19 \\
Thermal $\left(80^{\circ} \mathrm{C}\right)$ & 5 day & 98.24 & 1.53 & 98.21 \\
Light (photolytic degradation) & 5 day & 97.54 & 2.20 & 98.54 \\
\hline
\end{tabular}

\begin{tabular}{ccccc}
\hline & \multicolumn{4}{c}{ (b) } \\
\hline Stress condition & Time & \% Assay of Nimesulide & $\begin{array}{c}\text { \% Degradation } \\
\text { w.r.t control }\end{array}$ & $\begin{array}{c}\text { Mass balance (\% assay+ \% } \\
\text { degradation products) }\end{array}$ \\
\hline Control & $\mathrm{NA}$ & 100.21 & $\mathrm{NA}$ & 100.14 \\
Acid hydrolysis $(2 \mathrm{M} \mathrm{HCl})$ & $48 \mathrm{~h}$ & 95.87 & 4.34 & 98.01 \\
Base hydrolysis $(1 \mathrm{~N} \mathrm{NaOH})$ & $3 \mathrm{~h}$ & 78.22 & 21.99 & 97.52 \\
Oxidation $\left(3 \% \mathrm{H}_{2} \mathrm{O}_{2}\right)$ & $48 \mathrm{~h}$ & 96.24 & 3.97 & 99.19 \\
Thermal $\left(80^{\circ} \mathrm{C}\right)$ & 5 day & 98.24 & 1.97 & 98.21 \\
Light (photolytic degradation) & 5 day & 92.87 & 7.34 & 98.54 \\
\hline
\end{tabular}

Method validation study showed that the method is specific, linear, accurate, easily reproducible and can be used for simultaneous determination of camylofin dihydrochloride and Nimesulide from pharmaceutical preparations. Stress testing showed that all degradation products were well separated from Camylofin dihydrochloride and Nimesulide, confirming its stability indicating capability. The method seems to be suitable for quality control in the pharmaceutical industry because of its sensitivity, simplicity and selectivity.

\section{References}

[1] Sweetman and S. C. Martindale, "The Complete Drug Reference,” 36th Edition, 2009.

[2] M. J. Oneil, A. Smith and P. E. Heckelman, "The Merck Index,” 13th Edition, Merck \& Co. Inc, White House Station, 2001.

[3] G. Khaksa and N. Udupa, "Rapid and Sensitive Method for Determination of Nimesulide in Human Plasma by High-Performance Liquid Chromatography," Journal of Chromatography B: Biomedical Sciences and Applications, Vol. 727, No. 1-2, 1999, pp. 241-244. doi:10.1016/S0378-4347(98)00567-2

[4] D. J. Jaworowicz, M. T. Filipowski and K. M. K. Boje, "Improved High Performance Liquid Chromatographic Assay for Nimesulide," Journal of Chromatography B, Vol. 723, 1999, pp. 293-299. doi:10.1016/S0378-4347(98)00559-3

[5] S. S. Zarapkar, N. P. Bhandari and U. P. Halkar, "Simultaneous Determination of Nimesulide and Chlorzoxazone in Pharmaceutical Dosage by RP HPLC,” Indian Drugs, Vol. 37, 2000, p. 467.

[6] B. Raman and D. Patil, "RPHPLC for the Simultaneous Estimation of Tinidazole and Nimesulide in Tablets," Indian Drugs, Vol. 39, 2002, pp. 392-394.

[7] P. Kovaikova, M. Mokry and J. Klime, "Photochemical Stability of Nimesulide," Journal of Pharmaceutical and Biomedical Analysis, Vol. 31, No. 4, 2003, pp. 827-832. doi:10.1016/S0731-7085(02)00659-3

[8] B. S. Nagaralli, J. G. Seetharamappa, B. G. Gowda and M. B. Melwanki, "High Performance Liquid Chromatography Method for the Determination of Nimesulide in Pharmaceutical Preparations," Journal of Analytical Chemistry, Vol. 58, No. 8, 2003, pp. 873-875. doi:10.1023/A:1025095829622

[9] R. Nageswara Rao, S. Meena, D. Nagaraju, A. Raghu Ram Rao, "Development and Validation of a Reversedphase Liquid Chromatographic Method for Separation and Simultaneous Determination of COX-2 Inhibitors in Pharmaceuticals and Its Application to Biological Fluids,” Biomedical Chromatography, Vol. 19, No. 5, 2004, pp. 362-368. doi:10.1002/bmc.458

[10] P. D. Tzanavaras and D. G. Themelis, "Validated High-Throughput HPLC Assay for Nimesulide Using a Short Monolithic Column," Journal of Pharmaceutical and Biomedical Analysis, Vol. 43, No. 4, 2006, pp. 14831487. doi:10.1016/j.jpba.2006.10.014

[11] H. Nimje, S. P. Wate and D. P. Dharkar, "Determination of Nimesulide and Tizanidine in Tablets," Indian Journal of Pharmaceutical Sciences, Vol. 69, No. 2, 2007, pp. 281-283. doi:10.4103/0250-474X.33158

[12] M. Mokry, J. Klimes and J. Pechova, "HPLC Analysis of a Syrup Containing Nimesulide and Its Hydrolytic Deg- 
radation Product,” Chemical Papers, Vol. 64, 2010, pp. 405-408. doi:10.2478/s11696-010-0001-2

[13] F. A. Elbarbry, M. M. Mabrouk and M. A. El-Dway, "Determination of the Analgesic Components of Spasmomigraine Tablet by Liquid Chromatography with Ultraviolet Detection," Journal of AOAC International, Vol. 90, No. 1, 2007, pp. 94-101.

[14] P. S. Barde, A. Y. Desai, S. M. N. Roy and V. V. Vaidya, "Simultaneous RP HPLC Determination of Camylofin Dihydrochloride in Pharmaceutical Preparation," TSI Journal, Vol. 7, No. 10, 2008.

[15] R. R. Singh, M. V. Rathnam and R. Vegesna, "Simultaneous RP HPLC Determination of Camylofin Dihydrochloride and Paracetamol in Pharmaceutical Preparations,” TSI Journal, Vol. 7, No. 11, 2008.

[16] M. V. Rathnam and R. R. Singh, "Simultaneous RP HPLC Determination of Camylofin Dihydrochloride and Diclofenac Potassium in Pharmaceutical Preparations," Pharm Anal Acta, Vol. 1, No. 2, 2010, p. 1000108.

\section{doi:10.4172/2153-2435.1000108}

[17] E. Crombeza, W. Van Den Bosschea and P. De Moerloosea, "Gas Chromatographic Determination of Camylofine Dihydrochloride in Tablets and Suppositories," Journal of Chromatography A, Vol. 117, No. 1, 1976, pp 161-166. doi:10.1016/S0021-9673(00)81077-8

[18] L. R. Snyder, J. J. Kirland and J. L. Glajch, "Practical HPLC Method Development,” 2nd Edition, John Wiley and sons, Inc., Hokoben, 1997.

[19] ICH, "Validation of Analytical Procedures; Text and Methodology,” International Conference on Harmonization Guidance Documents, Q2 (R1), 2005.

[20] ICH, "Photo Stability Testing of New Drugs Substances and Products," International Conference on Harmonization Guidance Documents, Q1B, 2005.

[21] ICH, "Stability Testing of New Drug Substances and Products," International Conference on Harmonization Guidance Documents, Q1A (R20), 2005. 